OPEN ACCESS

Edited by:

Florence Rage,

Délégation Languedoc Roussillon

(CNRS), France

Reviewed by:

Gabriele Fuchs,

University at Albany, United States Maria Paola Paronetto,

Foro Italico University of Rome, Italy

*Correspondence:

Min Jeong Kye

min.kye@uk-koeln.de

Specialty section:

This article was submitted to

Protein and RNA Networks,

a section of the journal

Frontiers in Molecular Biosciences

Received: 20 September 2019 Accepted: 20 December 2019

Published: 15 January 2020

Citation:

Thelen MP and Kye MJ (2020) The Role of RNA Binding Proteins for Local mRNA Translation: Implications in Neurological Disorders.

Front. Mol. Biosci. 6:161 doi: 10.3389/fmolb.2019.00161

\section{The Role of RNA Binding Proteins for Local mRNA Translation: Implications in Neurological Disorders}

\author{
Maximilian Paul Thelen and Min Jeong Kye* \\ Institute of Human Genetics, University of Cologne, Cologne, Germany
}

As neurons are one of the most highly polarized cells in our body, they require sophisticated cellular mechanisms to maintain protein homeostasis in their subcellular compartments such as axons and dendrites. When neuronal protein homeostasis is disturbed due to genetic mutations or deletions, this often results in degeneration of neurons leading to devastating outcome such as spinal muscular atrophy (SMA), amyotrophic lateral sclerosis (ALS), and fragile $X$ syndrome (FXS). Ribonucleoprotein (RNP) complexes are macromolecular complexes composed of RNA binding proteins (RBPs) and their target RNAs. RBPs contain RNA binding domains and bind to RNA molecules via specific sequence motifs. RNP complexes have various functions in gene expression including messenger RNA ( $m R N A$ ) trafficking, RNA processing and silencing. In neurons, RBPs deliver specific sets of mRNAs to subcellular compartments such as axons and dendrites to be locally translated. Mutations or deletions in genes coding for RNPs have been reported as causes for neurological disorders such as SMA, ALS, and FXS. As RBPs determine axonal or dendritic mRNA repertoires as well as proteomes by trafficking selective mRNAs and regulating local protein synthesis, they play a crucial role for neuronal function. In this review, we summarize the role of well-known RBPs, SMN, TDP-43, FUS, and FMRP, and review their function for local protein synthesis in neurons. Furthermore, we discuss their pathological contribution to the neurological disorders.

\footnotetext{
Keywords: ribonucleoproteins, RNA binding proteins, mRNA translation, local protein synthesis, SMA, ALS, FXS, neurodegeneration
}

\section{INTRODUCTION}

Dysfunctional RNA processing in neuronal tissue is often observed in neurodegenerative diseases and plays a crucial role in neuronal pathology. This implies the essential part of ribonucleoprotein (RNP) complexes, that play an important role in RNA metabolism. RNP complexes contain RNA molecules with specific sequences/motifs bound to RNA-binding proteins (RBP). RNPs regulate eukaryotic gene expression in various cellular mechanisms including formation of ribosomes, spliceosomes and RNA-induced silencing complexes (RISCs) (Dreyfuss et al., 2002). In RNP complexes, RNAs and RBPs influence the fate of each other. On the one hand, RBPs act on processing, modification, stability, translation, and localization of RNAs, on the other hand, RNAs can regulate function, interaction, stability, and localization of RBPs. One example are long noncoding RNAs (lncRNAs). They can regulate the function of RBPs by recruiting transcription factors or chromatin-modifying complexes to chromatin (Cech and Steitz, 2014). One of the most wellcharacterized RNPs are messenger RNPs (mRNPs). They are composed of specific mRNAs and their 
mRNA-binding proteins (mRBPs). Assembly of the mRNPs can influence subcellular localization, post-transcriptional modification and translation of the transcripts. The misregulated assembly of mRNPs in the central nervous system (CNS) often leads to neurodegenerative diseases such as amyotrophic lateral sclerosis (ALS) and spinal muscular atrophy (SMA) (Shukla and Parker, 2016). In pathology, alterations in RNA metabolism manifest itself in misregulated splicing, adenylation, transcription, mRNA transport, translation, and modified decay. Those changes can be caused by various defects including reduced RBP expression, aggregation-prone RBPs or RBP sequestration in RNA foci. A detailed summary about general mechanisms involved in RNA metabolism in pathology can be found in a review by Nussbacher et al. (2019).

Due to the extreme cellular compartmentalization of neurons, it is essential to provide local mRNA transcripts and this especially makes neurons vulnerable to loss of RNPs. It has been suggested that neurons can regulate protein homeostasis at subcellular levels. Numerous evidences support this hypothesis that neurons can synthesize proteins at the synaptic compartment in response to extra stimuli. For example, the cellular components necessary to produce proteins are detected at the synaptic area such as ribosomes and mRNAs (Ainsley et al., 2014; Scarnati et al., 2018; Poulopoulos et al., 2019). In this scheme, RNPs deliver specific sets of mRNAs and produce repertoires of mRNAs in subcellular compartments, resulting in unique synaptic proteomes in neurons. Therefore, accurate function of RNPs and efficient local mRNA translation are crucial for neuronal development and function.

This review focuses on translational abnormalities caused by defects in mRNPs in neurological disorders including SMA, ALS, frontotemporal dementia (FTD), and fragile X syndrome (FXS). Table 1 summarizes the reviewed RBPs, the resulting neurodegenerative disorder as well as the underlying molecular mechanisms leading to pathology.

\section{PROTEIN SYNTHESIS IN NEURONS}

Protein synthesis is an essential cellular process for function, development and survival. In this process, a coordinated

TABLE 1 | Summary of RNPs in neurodegenerative disorders.

\begin{tabular}{|c|c|c|c|}
\hline Disease & RBP & Gene & Mechanism \\
\hline $\begin{array}{l}\text { Spinal muscular } \\
\text { atrophy (SMA) }\end{array}$ & $\begin{array}{l}\text { Survival motor neuron } \\
(\mathrm{SMN})\end{array}$ & $\begin{array}{l}\text { Homozygous } \\
\text { deletions, loss-of } \\
\text { function mutations }\end{array}$ & $\begin{array}{l}\text { Reduced RBP } \\
\text { expression }\end{array}$ \\
\hline $\begin{array}{l}\text { Amyotrophic } \\
\text { lateral sclerosis } \\
\text { (ALS), } \\
\text { Frontotemporal } \\
\text { dementia (FTD) }\end{array}$ & $\begin{array}{l}\text { TAR DNA binding } \\
\text { protein } 43 \text { (TDP-43), } \\
\text { Fused in } \\
\text { sarcoma/translocated } \\
\text { in liposarcoma } \\
\text { (FUS/TLS) }\end{array}$ & $\begin{array}{l}\text { Mutations, } \\
\text { mislocalization } \\
\text { (abberant } \\
\text { methylation) }\end{array}$ & $\begin{array}{l}\text { Aggregation- } \\
\text { prone RBP, RBP } \\
\text { sequestration in } \\
\text { RNA foci }\end{array}$ \\
\hline $\begin{array}{l}\text { Fragile X } \\
\text { syndrome (FXS) }\end{array}$ & $\begin{array}{l}\text { Fragile } X \text { mental } \\
\text { retardation protein } \\
(\text { FMRP) }\end{array}$ & $\begin{array}{l}\text { CGG>200 repeat } \\
\text { expansion in the } 5^{\prime} \\
\text { UTR of FMR1 }\end{array}$ & $\begin{array}{l}\text { Reduced RBP } \\
\text { expression, RBP } \\
\text { sequestration in } \\
\text { RNA foci }\end{array}$ \\
\hline
\end{tabular}

interplay between proteins and RNA is crucial to produce functional proteins. Mutations in genes involved in RNA metabolism lead to various diseases. Interestingly, many of these mutations are associated with neurodegenerative, neurodevelopmental and neuromuscular disorders. Because neurons are post-mitotic, highly polarized and larger in size compared to other types of cells, less severe mutations in genes involved in RNA metabolism may cause dysfunction in neurons, but other types of cells might tolerate these mutations. Dysfunction of RNA-related processes including tRNA synthesis, ribosome biogenesis, sequestration and mislocalization of mRNAs has been reported as pathological mechanisms in neurological disorders (Jordanova et al., 2006; Butterfield et al., 2014; Rossi et al., 2015). Furthermore, mutations in genes involved in RNA metabolisms are also reported as causative mutations in neurodegenerative diseases. For example, deletion of a gene coding for fragile $\mathrm{X}$ mental retardation protein (FMRP, a repressor of mRNA translation) causes mental retardation and mutations in a gene coding for TAR DNA binding protein (TDP43), which impairs protein synthesis by sequestering mRNAs, can cause ALS or frontotemporal dementia (Verkerk et al., 1991; Coyne et al., 2017).

Ribosomes are crucial components of mRNA translation. Recent data suggests that ribosomes are rather heterogeneous and this may affect protein synthesis efficiency in subcellular compartments (Simsek et al., 2017; Genuth and Barna, 2018). Mutations in genes important for ribosome biogenesis such as ribosomal protein and ribosomal RNA can cause neurodegenerative disorders (ribosomopathies) (Farley-Barnes et al., 2019). Besides the conventional cap-dependent translation initiation mechanism, Internal Ribosome Entry Site (IRES)mediated translation is reported in neurons (Pinkstaff et al., 2001; Pelletier and Sonenberg, 2019). While the pathogenic mechanism is unclear, it has been shown that TAU, which contributes to Alzheimer's pathology, is synthesized via IRES mediated translation initiation (Veo and Krushel, 2009). In addition, another non-conventional translation mechanism has been reported, repeat-associated non-AUG (RAN) translation. For example, a pathological expansion of trinucleotide repeats in C9ORF72 forms IRES like structures in RNA, producing toxic dipeptide repeats, which form aggregates in neurons (Ash et al., 2013; Zu et al., 2013). These dipeptide-containing aggregates are observed in ALS patient samples with mutations in C9ORF72 (Zu et al., 2013). Taken together, these findings highly suggest that protein synthesis is a particularly important process in neurons and its dysregulation can cause neuronal dysfunction.

\section{LOCAL MRNA TRANSLATION IN AXONS AND DENDRITES}

In neurons, mRNAs can be transported to axons and dendrites as mRNPs and locally translated to maintain local protein homeostasis. The localization sequence (also called zip code) to neuronal projections is often located in the $3^{\prime}$-untranslated region (UTR) of the mRNA (Andreassi and Riccio, 2009). It is believed that activity-dependent synaptic protein synthesis 
is crucial for learning and memory formation (Buffington et al., 2014). Cellular components necessary for regulating protein synthesis have been found in the neurite compartments including mRNAs, tRNAs, ribosomes, translation factors, the RNA-induced silencing complex (RISC) as well as microRNAs (miRNAs) (Tiedge and Brosius, 1996; Lugli et al., 2005; Kye et al., 2007; Ainsley et al., 2014; Scarnati et al., 2018; Poulopoulos et al., 2019). Local mRNA repertoire has been profiled in many different contexts by various methods (Matsumoto et al., 2007; Poulopoulos et al., 2019). In brief, transcriptomes and proteomes in growth cones isolated from cerebral cortices have been profiled by RNA sequencing and mass spectrometry (Poulopoulos et al., 2019). This data suggests that subcellular transcriptomes/proteomes play an important role in neural circuit formation and more interestingly, subcellular transcriptome distribution is mTOR dependent. In addition, dendritic RNAs have been identified from the synaptosomes by microarray analysis and their subcellular distribution can be altered by neuronal activity (Matsumoto et al., 2007). These data sets confirm that neuronal projections, either axons or dendrites contain different sets of mRNAs compared to soma. These findings highly suggest that local proteomes are supplied by local mRNAs. Recently, it has been identified that mitochondria and late endosomes play an important role for protein synthesis at the synaptic site (Cioni et al., 2019; Rangaraju et al., 2019). Due to these reports, late endosomes serve as a platform of axonal local translation by binding to RBPs, ribosomes and mRNAs. Furthermore, the proteins important for mitochondrial integrity are produced on the late endosomes (Cioni et al., 2019). Additionally, while it has been suggested that synaptic energy can be supplied by glycolysis in presynaptic boutons (Ashrafi et al., 2017), mitochondria seem to be the sole energy source for post-synaptic plasticity as mitochondria-depleted dendritic spines show clearly reduced levels of plasticity induced protein synthesis as well as spine growth (Rangaraju et al., 2019).

Another interesting cellular component regulating neuronal protein synthesis are RNA granules. Neurons contain various RNA granules including stress granule, processing body (P-body) and tRNP granule (Anderson and Kedersha, 2009). It has been suggested that RNA granules can repress protein synthesis and store mRNAs until they have reached their final subcellular destination in neurons (Kiebler and Bassell, 2006). Importantly, it has been shown that dendritically located RNP granules can be disassembled in an activity-dependent manner and mRNAs can be used as a template to produce synaptic proteins (Krichevsky and Kosik, 2001). This process is crucial for neuronal health and function as it is a cellular homeostatic mechanisms to handle external stress and control synaptic plasticity. While many RBPs are involved in assembly and disassembly of RNA granules, here we will focus on the RBPs whose dysfunction is associated with neurological disorders.

\section{AXONAL RNA BINDING PROTEINS AND AXONAL LOCAL TRANSLATION}

It is still not fully understood how (or even whether) proteins can be synthesized in mature axons in vivo, and whether this is a universal mechanism happening in all kinds of neurons or if it is a neuronal subtype specific phenomenon. However, increasing numbers of evidence suggest that active protein synthesis happens in growing and regenerating axons (Spaulding and Burgess, 2017). To characterize the axonal local translation mechanism, different approaches have been made including profiling axonal transcriptome/proteome and identifying RNA binding proteins for mRNA trafficking or splicing (Briese et al., 2018; Poulopoulos et al., 2019; Zhang et al., 2019). One of the most important player of protein synthesis, the ribosomes, are detected in axonal compartments (Akins et al., 2017). Axonal ribosomes can be trafficked from soma, but they can also be transferred from surrounding cells such as glia or Schwann cells via exosomes (Court et al., 2008; Muller et al., 2018). Another important component of translation are messenger RNAs (mRNAs). As mentioned above, RBPs bind to mRNAs selectively, localize them in subcellular compartments and even regulate protein synthesis. This will impact on local proteome composition. For example, the zip code binding protein 1 (ZBP1) binds the $3^{\prime}$-UTR of $\beta$-actin mRNA and hinders protein synthesis by blocking translation initiation as long as $\beta$-actin mRNA is not localized to its destination (Huttelmaier et al., 2005). Next, mTOR kinase is an essential regulator of mRNA translation in injured axons (Terenzio et al., 2018). The mTOR kinase can regulate the efficiency of protein synthesis upon extracellular signals or intracellular status via turning on signaling cascades. Finally, numerous miRNAs and protein components of RISC have been detected in axons and growth cones (Hengst et al., 2006; Kye et al., 2014; Gershoni-Emek et al., 2018). This data implies that miRNAs can function as a translational repressor in axons. For example, it has been shown that miR-183 can repress protein synthesis of mTOR by direct binding to $3^{\prime} \mathrm{UTR}$ of $m$ TOR mRNA in axons (Kye et al., 2014). Taken together, with current knowledge, we can conclude that proteins can be synthesized in axonal compartments.

\section{Spinal Muscular Atrophy (SMA)}

SMA is caused by a reduction of the ubiquitously expressed SMN protein which leads to loss of lower motor neurons. In more than $95 \%$ of SMA cases, homozygous deletions are found in the SMN1 gene encoding the full length SMN protein. Humans possess a duplication of the SMN1 gene, SMN2, which produces a transcript lacking exon 7 due to a single point mutation located in exon 7 (Lorson et al., 1999). Due to this, SMN2 encodes for a unstable SMN protein, which is rapidly degraded by the proteasome pathway (Chang et al., 2004). Therefore, the copy number of SMN2 can determine the amount of SMN proteins and the severities of SMA (Butchbach, 2016). Importantly, complete loss of SMN is embryonically lethal in multiple organisms including humans and mice (Schrank et al., 1997). Therefore, SMA mouse models are generated by introducing human SMN2 genes in murine Smn-null background. Two copies of SMN2 in Smn null background causes severe phenotypes in mice mimicking type I SMA patients. In this model, mice are born with a normal number of motor neurons, but lose 3-40\% of spinal cord and lower brainstem motor neurons by postnatal day 5 (Monani et al., 2000). It is still under investigation how a ubiquitously expressed protein like SMN leads to specific 
loss of lower motor neurons in SMA. It has been hypothesized that specific sets of primary mRNAs are dysregulated in SMA and that they are crucial for development and survival of motor neurons. For example, Agrin (Agrn) is mis-spliced in motor neurons of SMA mice, and notably it is important for organizing acetylcholine receptors at the NMJ (Zhang et al., 2013; Kim et al., 2017). Furthermore, an alternatively spliced form of SMN, the axonal-SMN (a-SMN) has been reported. This isoform seems highly expressed in the axonal compartment of motor neurons and it enhances axon growth in neurons. While the molecular mechanism underlying the role of a-SMN in axonogenesis remains still unclear, this might hint at the selective phenotype of SMN loss in motor neurons (Setola et al., 2007). Collectively, the functions of SMN with respect to RNA homeostasis are shown in Figure 1.

Splicing correction of SMN2 using an antisense oligonucleotide (ASO) has been developed to restore SMN protein levels. Briefly, ASO binds to an intronic silencer in intron 7 and thereby it enhances the inclusion of exon 7 of SMN2 (Hua et al., 2008, 2011). Noteworthy, this ASO-mediated treatment, named Nusinersen became the first Food and Drug Administration (FDA) approved treatment for SMA. In addition, gene therapy using AAV9 has been also FDA-approved as a SMA therapy. As SMA is caused by deficiency of SMN protein, SMN protein can be restored in motor neurons by viral delivery (Mendell et al., 2017).

\section{Survival Motor Neuron (SMN) for Local mRNA Translation}

As mentioned above, SMA is caused by SMN protein deficiency. SMN is an RNA binding protein, ubiquitously expressed and performs multiple essential cellular functions, especially in RNA processing. SMN protein levels are higher during embryogenesis and decrease after birth (Jablonka and Sendtner, 2017). Correlating with SMN levels, assembly of small nucleolar ribonucleoproteins (snRNP) declines in mouse spinal cord during the early postnatal weeks (Gabanella et al., 2005). Basic SMN complex consists of SMN and Gemin 2-8, and SMN protein itself is rather unstable without its binding partners (Lorson et al., 1998; Otter et al., 2007). Reactive oxygen species (ROS) can inhibit SMN complex formation. Even subtoxic levels of ROS can inhibit SMN complex formation by inducing intramolecular disulfide bridging (Wan et al., 2008). Activity of the SMN complex is regulated by phosphorylation, and phosphorylation of SMN enhances cytoplasmic localization and snRNP biogenesis (Grimmler et al., 2005; Renvoise et al., 2012). The SMN complex can be detected in the cytoplasm, nucleus and nuclear gems (Gemini of Cajal bodies) (Carvalho et al., 1999). SMN levels are

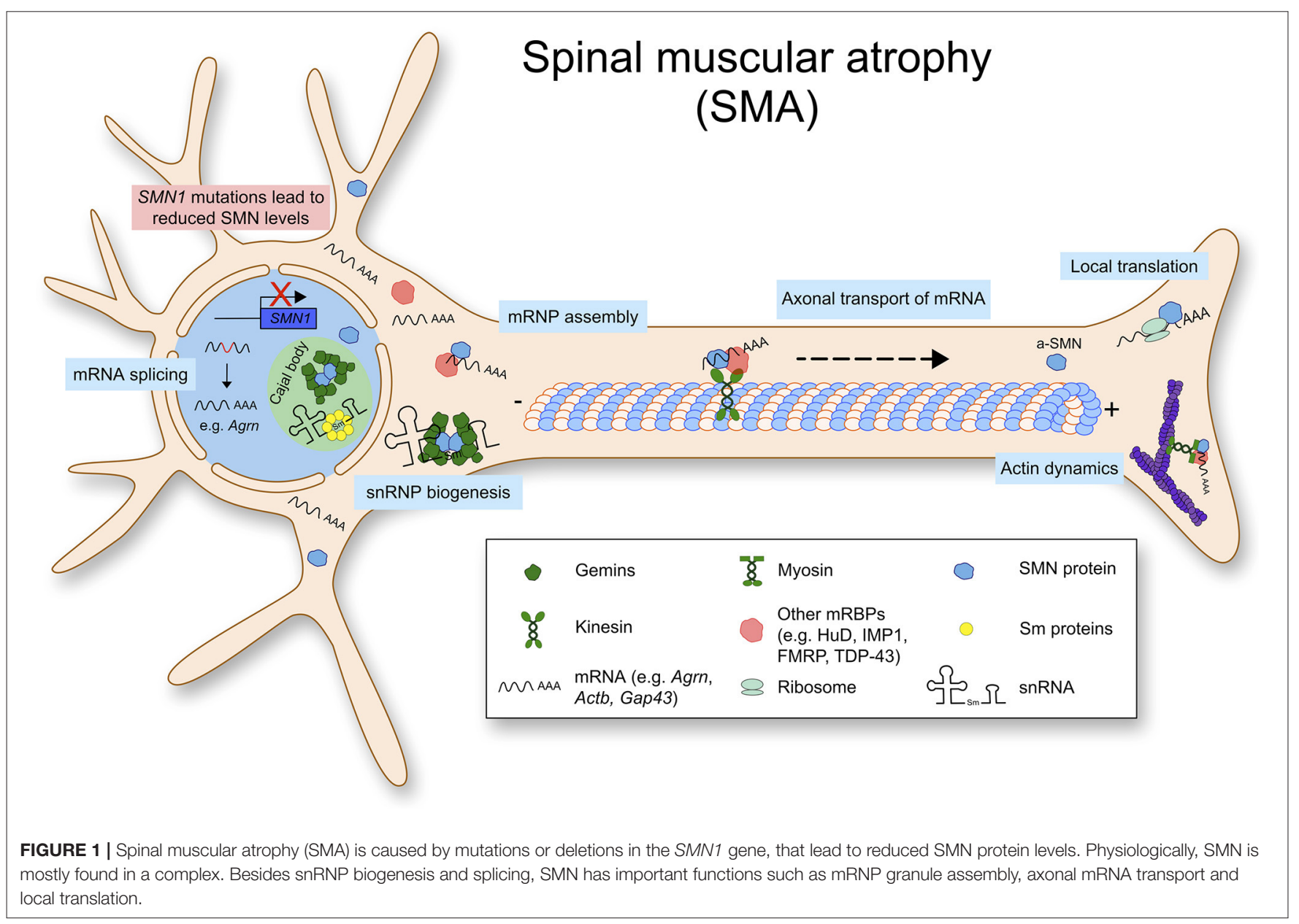


especially higher in nuclear gems, which consist of RNAs and proteins. It has been suggested that the composition of SMN complex can be different in neurite compartments of neurons (Todd et al., 2010).

SMN complex is a molecular chaperone, regulating structure, biogenesis and function of snRNPs that are involved in splicing (Liu and Dreyfuss, 1996). For snRNP biogenesis, SMN facilitates the assembly of Sm proteins onto the Sm site of the snRNA and produces functional snRNPs (also known as spliceosomes). SMN also functions in the transport and assembly of other ribonucleoprotein classes, including microRNPs or telomerase RNPs (Buhler et al., 1999; Mourelatos et al., 2001, 2002).

SMN is involved in mRNA processing after being assembled into mRNPs. These additional functions range from nuclear export, intracellular trafficking to translation. In neurons, SMN binds to mRNAs directly or via other mRBPs, and transports polyA-tailed mRNAs to the axonal compartment to be locally translated (Akten et al., 2011; Fallini et al., 2011; Ottesen et al., 2018). Such mRBPs include HuD (ELAVL4, ELAV like RNA binding protein 4), KSRP (KH-type splicing regulatory protein), hnRNPs (heterogeneous nuclear ribonucleoproteins) and IMP1 (also known as IGF2BP1, Insulin like growth factor 2 mRNA binding protein 1) (Tadesse et al., 2008; Akten et al., 2011; Dombert et al., 2014; Fallini et al., 2014). The known Smn mRNA cargo in neurons include mRNAs of $\beta$-actin, growth-associated protein 43 (Gap43), annexin 2 (Anxa2), and neuritin/cpg15 (Akten et al., 2011; Fallini et al., 2016; Rihan et al., 2017; Ottesen et al., 2018). Stable supply of $\beta$-actin protein seems important for growth of neurons as a building block, GAP43 is crucial for axonal pathfinding and regeneration, CPG15 is a known neurotrophic factor, and ANXA2 is also important for growth of cells. It is also worth to note that rapid bidirectional transport of SMN protein has been observed in primary neurons and it is microtubule dependent (Zhang et al., 2003). Taken together, these data collectively suggest that SMN plays an important role for local proteome composition by trafficking mRNAs, to be translated in the axonal compartment.

\section{Amyotrophic Lateral Sclerosis (ALS) and Frontotemporal Dementia (FTD)}

ALS is an adult-onset, progressive neurodegenerative disorder causing deterioration and death of upper and lower motor neurons (Cleveland and Rothstein, 2001). Most of ALS patients die from respiratory failure within 3-5 years after onset (Swinnen and Robberecht, 2014). The majority of ALS cases (90-95\%) is considered as sporadic ALS (sALS) without family history and $5-10 \%$ of cases show Mendelian inheritance. Over the last decades, genetic variants in over 25 genes are associated with ALS (Nguyen et al., 2018). The most common and most well established mutations contributing to ALS pathology are found in $\mathrm{Cu}-\mathrm{Zn}$ superoxide dismutase 1 (SOD1), TDP-43, FUS and a hexanucleotide expansion repeat in Chromosome 9 Open Reading Frame 72 (C9orf72) (Chia et al., 2018). Mutations in SOD1 are the first reported ALS- associated mutations and are the second most common mutations in ALS (Rosen et al., 1993). Those mutations in SOD1 can be found in about $12 \%$ of familial ALS (fALS) and around 1\% sALS (Renton et al., 2014). The most common mutated gene in ALS and FTD is C9orf72, which forms highly stable RNA G-quadruplexes due to a hexanucleotide repeat in the $5^{\prime}$ non-coding region (Renton et al., 2011). Up to now, the protein function of C9ORF72 is rather unknown, but the formation of G-quadruplexes are involved in sequestering RNA metabolism such as telomere stability, transcription, splicing, RNA transport, and translation in RNA foci (Fratta et al., 2012). More importantly, a hexanucleotide repeat in the $5^{\prime}$ non-coding region of $\mathrm{C} 9$ orf 72 can produce dipeptide repeat proteins (Gly-Ala) via RAN translation. These dipeptide proteins form aggregates in neurons and cause cellular toxicity (May et al., 2014). In 2008, mutations in the gene coding for the transactive response DNA-binding protein 43 (TDP43) have been reported as disease causing mutations in ALS (Sreedharan et al., 2008). A recent study showed that mutations in TDP-43 account for $4 \%$ of fALS and for $<1 \%$ of sALS cases (Chia et al., 2018).

In addition to ALS, mutations in TDP-43 can lead to frontotemporal lobar degeneration (FTLD-TDP), which is characterized by insoluble inclusions containing TDP43 aggregates (Seelaar et al., 2007). TDP-43 proteinopathies show various molecular phenotypes including loss of nuclear expression and pathological aggregations (Winton et al., 2008; Zhang et al., 2009). The molecular mechanisms contributing to ALS and FTD pathology are summarized in Figure 2. At the moment, it is unclear whether TDP-43 mediated neurodegeneration is caused by the loss of function or the gain of toxic function.

\section{Transactive Response DNA-Binding Protein 43 (TDP-43) for Local mRNA Translation}

TDP-43 is a $43 \mathrm{kDa}$ highly conserved, ubiquitously expressed DNA/RNA-binding protein, encoded by the TARDP gene in humans. It plays an important role in RNA processing and its mutations are linked to neurodegeneration (Lee et al., 2011). TDP-43 binds to a large variety of transcripts including mRNAs and non-coding RNAs (Sephton et al., 2011; Tollervey et al., 2011). Interestingly, some of those transcripts are related to neuronal development or synaptic activity (Polymenidou et al., 2011). Furthermore, TDP-43 also regulates microRNA (miRNA) biogenesis by binding to the Drosha-DGCR8 (DiGeorge syndrome critical region gene 8) microprocessor complex, which is important for processing primary miRNAs. Indeed, knockdown of TDP-43 results in altered levels of miRNAs (Kawahara and Mieda-Sato, 2012).

In addition to the RNA binding motifs, TDP-43 contains a C-terminal low complexity domain, where the majority of ALSassociated dominant missense mutations are located (Figure 3) (Pesiridis et al., 2009). It has been shown that TDP-43 binds to the hnRNPs including hnRNP A1, hnRNP A2/B1, hnRNP A3, and hnRNP C1/C2 via this glycine-rich domain (Buratti et al., 2005; Freibaum et al., 2010). Interestingly, TDP-43 regulates splicing of several transcripts including Smn mRNA (Bose et al., 2008). Various stressors mediate the redistribution of TDP-43 from the nucleus into the cytoplasm, where it is associated with RNAs and 


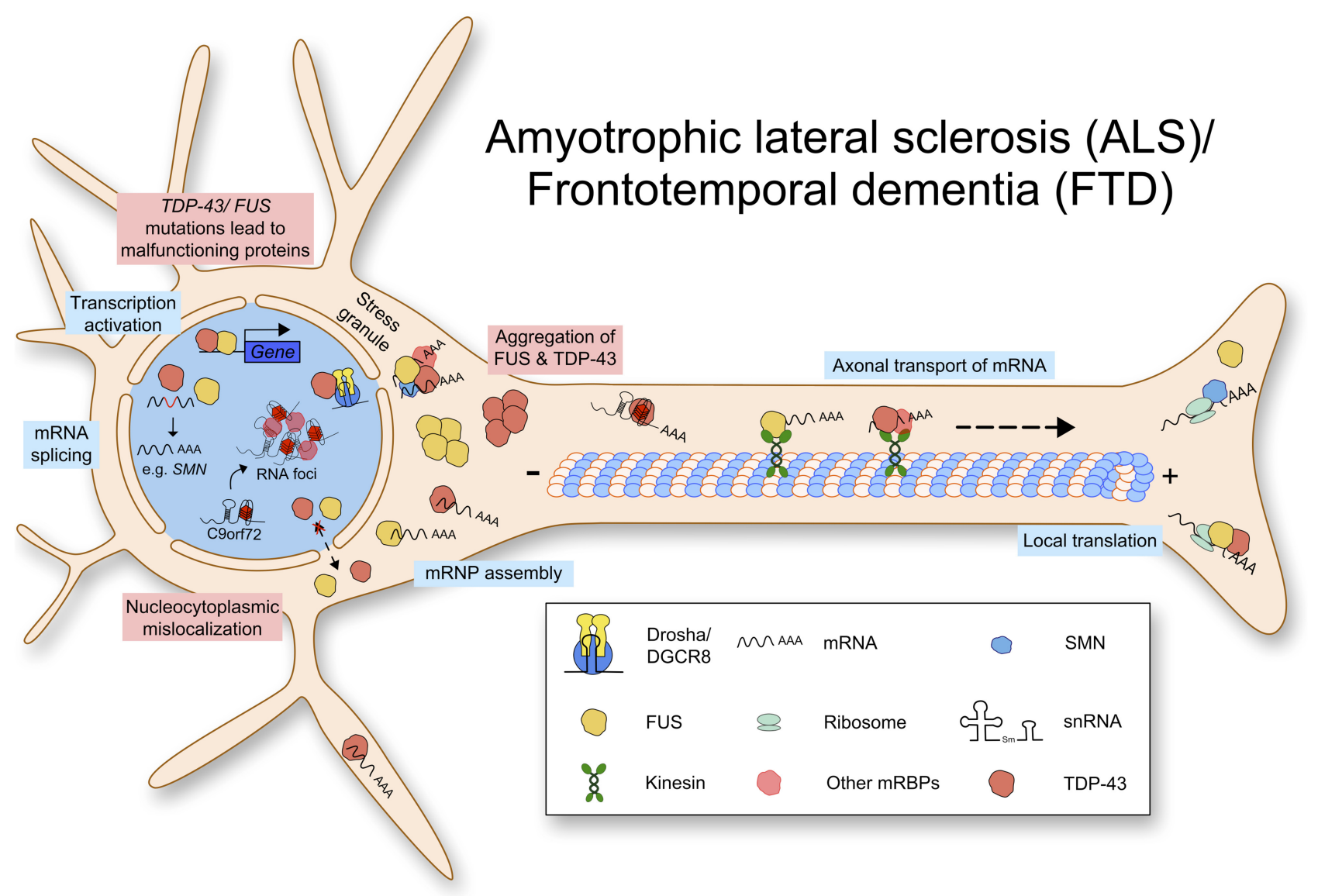

FIGURE 2 | Amyotrophic lateral sclerosis (ALS) and Frontotemporal dementia (FTD) are caused by multiple mutations leading to defects in RNA metabolism. Mutated TDP-43 or FUS protein aggregates in the cytoplasm and lacks nuclear import. TDP-43 and FUS function physiologically in transcription activation, mRNA splicing, mRNP assembly, axonal transport of mRNA, and local translation. Due to loss of normal protein function and gain of toxic function, RNA metabolism is impaired.

recruited to stress granules (Colombrita et al., 2009; Dewey et al., 2011; Mcdonald et al., 2011).

In neurons, TDP-43 binds to specific RNA structures, G-quadruplex in mRNAs and deliver them to neurites to be translated locally. Interestingly, TDP-43 protein with an ALS-linked mutation in the C-terminal glycine-rich domain diminishes the binding affinity to G-quadruplex in mRNAs and their translation in neurites (Ishiguro et al., 2016). Furthermore, ALS associated mutations in TDP-43 impairs mRNA trafficking in axons (Alami et al., 2014). Taken together, these data imply that disturbed local mRNA translation contributes to pathology of ALS. It is worthy to note that TDP-43 is also crucial for regulating dendritic local translation in response to neuronal activity (Endo et al., 2018). This may suggest the role of TDP-43 for psychiatric outcomes observed in FTD patients.

\section{Fused in Sarcoma/Translocated in Liposarcoma (FUS) for Local mRNA Translation}

Fused in sarcoma/Translocated in liposarcoma (FUS/TLS) is a DNA/RNA-binding protein and mutations in FUS are implicated in ALS (about $4 \%$ of fALS and $<1 \%$ of sALS) and FTLD (Chia et al., 2018). FUS can shuttle between the nucleus and cytoplasm, and is detected at the pre-synaptic site of hippocampal neurons and at the neuromuscular junction (NMJ) (Schoen et al., 2015; So et al., 2018). FUS plays various cellular functions including transcriptional activation, RNA splicing, mRNA trafficking and translation, and DNA repair as well as genome stability by direct binding to nucleic acid molecules (Efimova et al., 2017). It has been shown that FUS can act on mRNA trafficking and local translation in neurons. Importantly, ALS-causing mutant FUS harboring neurons showed impaired axonal protein synthesis (Lopez-Erauskin et al., 2018). Additionally, FUS protein has been detected in stress granules, which is known to function in translation repression (Bosco et al., 2010). However, it is still unclear whether wild-type FUS can be assembled into stress granules or this is an exclusive phenotype of mutant FUS (Aulas and Vande Velde, 2015).

Several mutations in FUS have been associated with ALS/FTD. Unlike TDP-43, where the majority of mutations linked to ALS/FTD are located in the low complexity domain, most ALS/FTLD-associated mutations are found in the C-terminal nuclear localization signal (NLS) in FUS (Figure 3) (Da Cruz 


\section{TAR DNA binding protein 43 (TDP-43)}

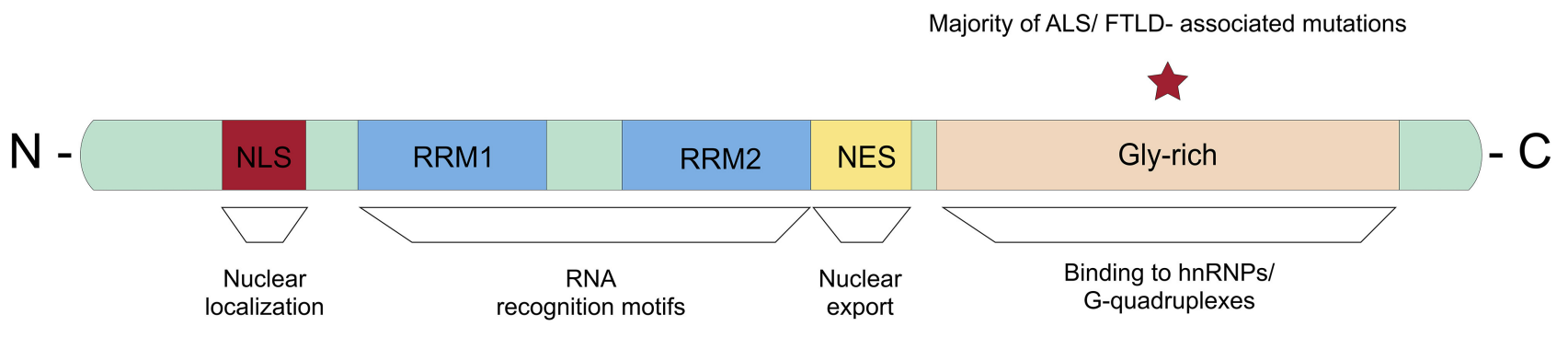

Fused in sarcoma (FUS)

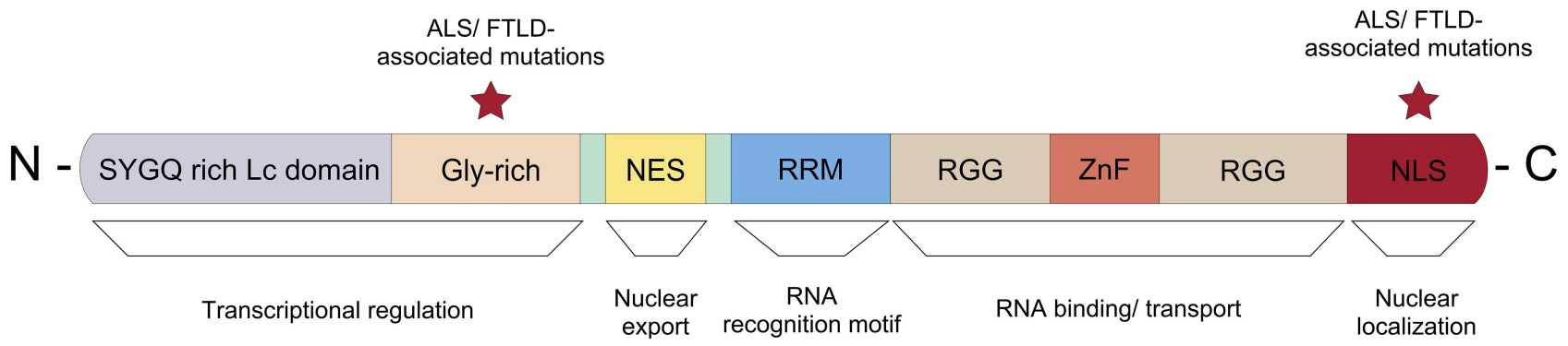

FIGURE 3 | Representation of the protein domain structure of TDP-43 and FUS. The majority of ALS/FTD associated dominant missense mutations in TDP-43 can be found in the glycine-rich c-terminus. Whereas, most ASL/FTLD associated mutations in FUS are described in the nuclear localization signal (NLS).

and Cleveland, 2011). Due to mutations in the NLS, mutant FUS proteins seem mis-localized and form inclusions in the cytoplasm (Vance et al., 2009). Proteomic approaches showed that these inclusions contain various proteins important for mRNA splicing, RNA processing and transport such as eIF4A3 (eukaryotic translation initiation factor 4A3) and eIF3 (eukatyotic translation initiation factor 3). Importantly, FUS regulates mRNA translation and non-sense mediated decay (NMD), and mutations in FUS suppress protein synthesis efficiency and cause hyperactive NMD resulting in impaired protein homeostasis in cells (Kamelgarn et al., 2018). In summary, mutant FUS induces inclusions, and this sequesters important proteins for cellular processes such as mRNA translation and NMD, which can be detrimental to cellular function and survival.

Interestingly, it has been shown that motor and cognitive deficits in ALS are caused by increase of mutant FUS in axonal compartments, that lead to reduced intra-axonal translation and therefore to synaptic dysfunction (Lopez-Erauskin et al., 2018). This decreased protein synthesis is not accompanied with FUS aggregation or loss of nuclear FUS function, suggesting a new patho-mechanism caused by mutant FUS.

Notably, FUS can interact with TDP-43. This interaction is increased by ALS-associated mutations in TDP-43 (Ling et al., 2010). Therefore, mutations in TDP-43 and FUS might share a common mechanism leading to ALS. In addition, FUS can interact with SMN and their binding affinity to each other increases by mutations in FUS. Furthermore, FUS inclusions sequester cytoplasmic SMN, resulting in reduced axonal SMN levels (Groen et al., 2013). As SMN delivers mRNAs to axons and growth cones for local translation (Akten et al., 2011), this data suggests that mutations in FUS induce impaired axonal local translation by sequestering the axonal SMN-mRNA complex. Taken together, these data imply that ALS and SMA might have a common patho-mechanisms such as decreased mRNP activity by SMN and impaired axonal local translation. Similar to TDP43, the gain of toxic function and/or loss of normal function in FUS contributes to ALS pathology.

\section{DENDRITIC RNA BINDING PROTEINS AND LOCAL MRNA TRANSLATION}

\section{Fragile X Syndrome (FXS)}

Fragile X syndrome (FXS) is a genetic disorder with intellectual disability caused by loss/deficiency of fragile X mental retardation protein, FMRP. FMRP is a polyribosome-associated RNA binding protein, which is encoded by the fragile $\mathrm{X}$ mental retardation 1 gene (FMR1) (Flannery et al., 1995). Mutations in the FMR1 gene are also associated with other diseases including 
the fragile $\mathrm{x}$-associated tremor/ataxia syndrome, premature ovarian aging and the polycystic ovarian syndrome (Kenneson and Warren, 2001). Mostly, loss of FMRP protein is caused by a trinucleotide repeat expansion in the $5^{\prime}$-UTR of FMR1. When this triple repeat exceeds 200 repeats, it is methylated together with the FMR1 promoter, resulting in transcriptional repression. In addition, missense mutations leading to FMRP dysfunction have been identified as a cause for physical disability as well as cognitive and behavioral impairments (Sitzmann et al., 2018; Maddirevula et al., 2019).

\section{Fragile X Mental Retardation Protein (FMRP) for Local mRNA Translation}

FMRP contains three RNA binding domains; two ribonucleoprotein $\mathrm{K}$ homology domains ( $\mathrm{KH}$ domains) and one RGG domain, which can bind to poly-riboguanylic acid (Ashley et al., 1993). FMRP is a well-described translational repressor in neurons and FMRP deficient neurons show a delayed maturation and abnormal morphology of the dendritic spines (Comery et al., 1997; Weiler and Greenough, 1999). While there are exceptions, FRMP represses mRNA translation via direct binding to G-quadruplexes in target mRNAs (Schaeffer et al., 2001). Interestingly, it has been shown that translation can be inhibited by FMRP binding to the inter-subunit space of the ribosome and this process is independent of G-quadruplexes on the target mRNA (Chen et al., 2014).

While we discuss the role of FMRP in dendritic local translation in this review, FMRP can be detected in axons together with microRNAs and mRNAs, suggesting its role for axonal local translation (Hengst et al., 2006). In sensory neurons, FMRP granules delivers mRNAs such as Map1b and Calm1 to axonal compartments, and release them to be translated upon stimulation by nerve growth factor (NGF). This process is important to NGF induced axonal outgrowth (Wang et al., 2015).

The cellular mechanism of dendritic local translation has been intensively studied as well as the role of FMRP in postsynaptic protein synthesis. FMRP participates in dendritic local translation in various steps (Figure 4). First, as mentioned above, FMRP binds to certain sets of mRNAs and delivers them to dendritic compartments. The experimentally validated FMRP binding mRNAs include its own mRNA Fmr1, Dlg4 (PSD95), and Mmp-9 (Matrix metalloprotease 9) (Schaeffer et al., 2001; Zalfa et al., 2007; Janusz et al., 2013; Ifrim et al., 2015). Surprisingly, high throughput sequencing of RNAs isolated by

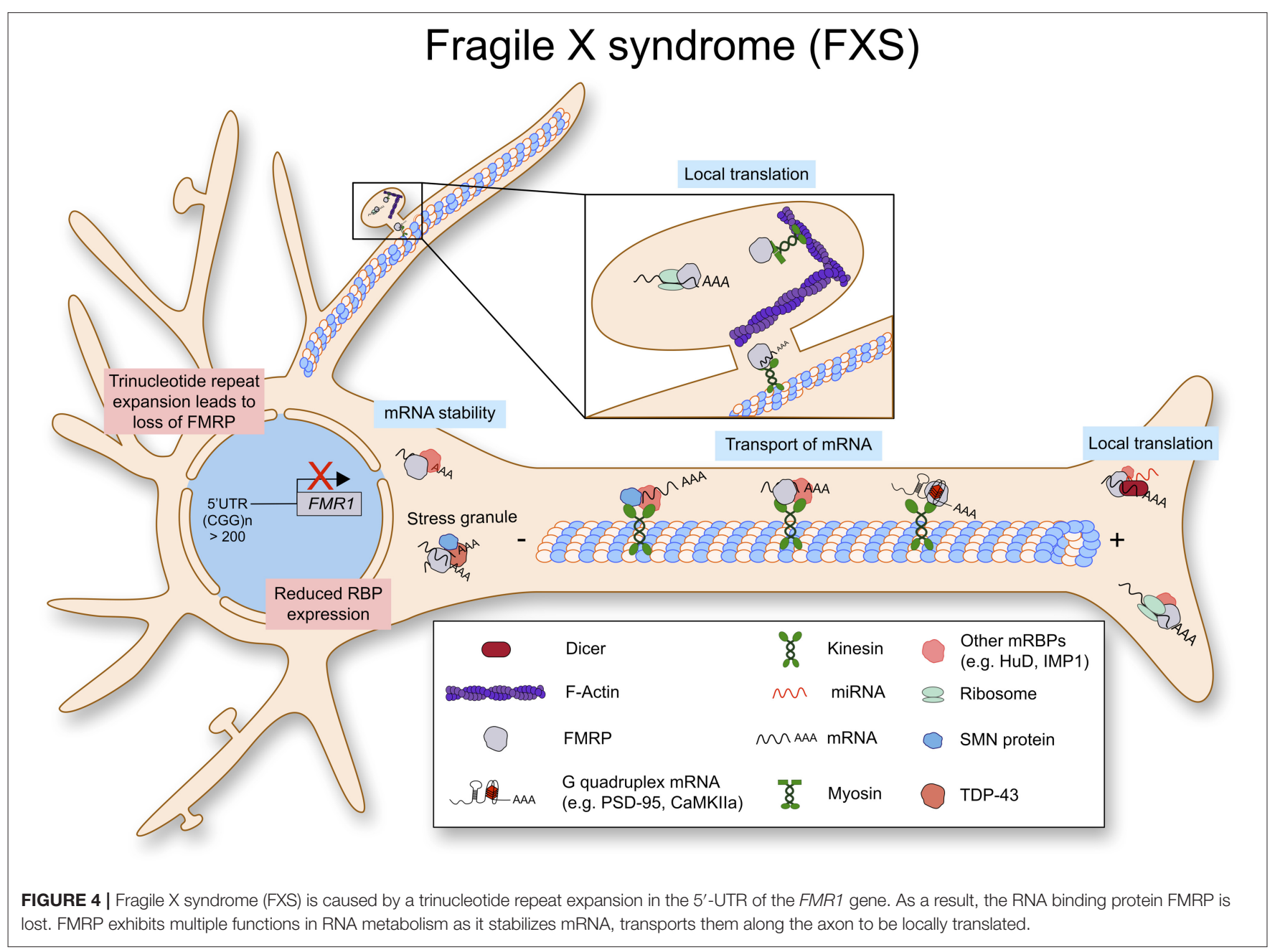


crosslinking immunoprecipitation (CLIP) assay has revealed that FMRP binds to 842 mRNAs, and $32 \%$ of them code for synaptic proteins (Darnell et al., 2011). This work has been further confirmed by independent experiments (Ascano et al., 2012; Maurin et al., 2018). Second, FMRP can repress translation by binding to mRNAs via non-coding RNA BC1. In this case, FMRP doesn't bind to mRNA directly, but $\mathrm{BC} 1$ mediates FMRP function on translation (Zalfa et al., 2003). Third, FMRP can stall ribosomes on mRNAs. It seems that FMRP binds to ribosomes and inhibits the elongation process (Darnell et al., 2011; Chen et al., 2014). Fourth, FMRP binds to RNA induced silencing complex (RISC) and regulates microRNA function for translational repression (Muddashetty et al., 2011). In brief, FMRP regulates mRNA translation of PSD-95 via miR125a containing RISC. Finally, post-translational modifications of FMRP also play an important role in mRNA translation via mRNA granule assembly. Recent papers suggest that phosphorylation of FMRP induces mRNA granule formation, which can sequester mRNAs and proteins, resulting in inhibition of new protein synthesis. Instead, methylation of FMRP in its arginine-glycine rich (RGG) domain can cause disassembly of mRNA granules leading to translational activation (Tsang et al., 2019). While further in vivo studies are required, this data unveiled a new cellular mechanism underlying neuronal activity induced FMRP-mediated protein synthesis at the synaptic site. Taken together, FMRP regulates local mRNA translation in neurons via multiple layers of cellular mechanisms.

\section{DISCUSSION AND SUMMARY}

Here, we have reviewed the current knowledge about the role of RNA binding proteins in local protein synthesis in

\section{REFERENCES}

Ainsley, J. A., Drane, L., Jacobs, J., Kittelberger, K. A., and Reijmers, L. G. (2014). Functionally diverse dendritic mRNAs rapidly associate with ribosomes following a novel experience. Nat. Commun. 5:4510. doi: 10.1038/ncomms5510

Akins, M. R., Berk-Rauch, H. E., Kwan, K. Y., Mitchell, M. E., Shepard, K. A., Korsak, L. I., et al. (2017). Axonal ribosomes and mRNAs associate with fragile X granules in adult rodent and human brains. Hum. Mol. Genet. 26, 192-209. doi: $10.1093 / \mathrm{hmg} / \mathrm{ddw} 381$

Akten, B., Kye, M. J., Hao Le, T., Wertz, M. H., Singh, S., Nie, D., et al. (2011). Interaction of survival of motor neuron (SMN) and $\mathrm{HuD}$ proteins with mRNA cpg15 rescues motor neuron axonal deficits. Proc. Natl. Acad. Sci. U.S.A. 108, 10337-10342. doi: 10.1073/pnas. 1104928108

Alami, N. H., Smith, R. B., Carrasco, M. A., Williams, L. A., Winborn, C. S., Han, S. S. W., et al. (2014). Axonal transport of TDP-43 mRNA granules is impaired by ALS-causing mutations. Neuron 81, 536-543. doi: 10.1016/j.neuron.2013.12.018

Anderson, P., and Kedersha, N. (2009). RNA granules: post-transcriptional and epigenetic modulators of gene expression. Nat. Rev. Mol. Cell. Biol. 10, 430-436. doi: $10.1038 / \mathrm{nrm} 2694$

Andreassi, C., and Riccio, A. (2009). To localize or not to localize: mRNA fate is in 3'UTR ends. Trends Cell. Biol. 19, 465-474. doi: 10.1016/j.tcb.2009.06.001

Ascano, M. Jr., Mukherjee, N., Bandaru, P., Miller, J. B., Nusbaum, J. D., Corcoran, D. L., et al. (2012). FMRP targets distinct mRNA sequence elements to regulate protein expression. Nature 492, 382-386. doi: 10.1038/nature11737 subcellular compartments of neurons. While there are many more RNA binding proteins in neurons and their roles are equally important and interesting, we have only covered the most well-known four proteins, SMN, TDP-43, FUS, and FMRP. Importantly, dysregulation of these proteins caused by mutations and deletions is often associated with human neurological disorders. As neurons are highly polarized, often large in size, and their function is transient, neuronal protein homeostasis needs to be regulated timely and spacially. Neurons solve this issue by quick production of proteins at local sites when new proteins are required. For this process, RNA binding proteins traffic mRNAs and store them in $\mathrm{mRNP}$ granules in synaptic compartments, and upon stimulus, mRNA can be released to produce new proteins. As this process is important for neuronal function, dysfunction of RNA binding proteins often cause neurological disorders, in the worst case, leading to organismal death. While many underyling cellular mechanisms have been characterized, the molecular functions and biophysical properties of RNA binding proteins are still not fully understood. Furthermore, it will be important to understand how dysfunctional RNA binding proteins and impaired local translation contribute to pathology of human diseases.

\section{AUTHOR CONTRIBUTIONS}

All authors listed have made a substantial, direct and intellectual contribution to the work, and approved it for publication.

\section{FUNDING}

This work was funded by DFG (MK, KY96/1-2) and SMA Europe (MK).

Ash, P. E., Bieniek, K. F., Gendron, T. F., Caulfield, T., Lin, W. L., Dejesus Hernandez, M., et al. (2013). Unconventional translation of C9ORF72 GGGGCC expansion generates insoluble polypeptides specific to c9FTD/ALS. Neuron 77, 639-646. doi: 10.1016/j.neuron.2013.02.004

Ashley, C. T. Jr., Wilkinson, K. D., Reines, D., and Warren, S. T. (1993). FMR1 protein: conserved RNP family domains and selective RNA binding. Science 262, 563-566. doi: 10.1126/science.7692601

Ashrafi, G., Wu, Z., Farrell, R. J., and Ryan, T. A. (2017). GLUT4 mobilization supports energetic demands of active synapses. Neuron 93, 606-615.e603. doi: 10.1016/j.neuron.2016.12.020

Aulas, A., and Vande Velde, C. (2015). Alterations in stress granule dynamics driven by TDP-43 and FUS: a link to pathological inclusions in ALS? Front. Cell. Neurosci. 9:423. doi: 10.3389/fncel.2015.00423

Bosco, D. A., Lemay, N., Ko, H. K., Zhou, H., Burke, C., Kwiatkowski, T. J. Jr., et al. (2010). Mutant FUS proteins that cause amyotrophic lateral sclerosis incorporate into stress granules. Hum. Mol. Genet. 19, 4160-4175. doi: 10.1093/hmg/ddq335

Bose, J. K., Wang, I. F., Hung, L., Tarn, W. Y., and Shen, C. K. (2008). TDP-43 overexpression enhances exon 7 inclusion during the survival of motor neuron pre-mRNA splicing. J. Biol. Chem. 283, 28852-28859. doi: 10.1074/jbc.M805376200

Briese, M., Saal-Bauernschubert, L., Ji, C., Moradi, M., Ghanawi, H., Uhl, M., et al. (2018). hnRNP R and its main interactor, the noncoding RNA 7SK, coregulate the axonal transcriptome of motoneurons. Proc. Natl. Acad. Sci. U.S.A. 115, E2859-E2868. doi: 10.1073/pnas.1721670115 
Buffington, S. A., Huang, W., and Costa-Mattioli, M. (2014). Translational control in synaptic plasticity and cognitive dysfunction. Annu. Rev. Neurosci. 37, 17-38. doi: 10.1146/annurev-neuro-071013-014100

Buhler, D., Raker, V., Luhrmann, R., and Fischer, U. (1999). Essential role for the tudor domain of SMN in spliceosomal $U$ snRNP assembly: implications for spinal muscular atrophy. Hum. Mol. Genet. 8, 2351-2357. doi: $10.1093 / \mathrm{hmg} / 8.13 .2351$

Buratti, E., Brindisi, A., Giombi, M., Tisminetzky, S., Ayala, Y. M., and Baralle, F. E. (2005). TDP-43 binds heterogeneous nuclear ribonucleoprotein A/B through its C-terminal tail: an important region for the inhibition of cystic fibrosis transmembrane conductance regulator exon 9 splicing. J. Biol. Chem. 280, 37572-37584. doi: 10.1074/jbc.M505557200

Butchbach, M. E. (2016). Copy number variations in the survival motor neuron genes: implications for spinal muscular atrophy and other neurodegenerative diseases. Front. Mol. Biosci. 3:7. doi: 10.3389/fmolb.2016.00007

Butterfield, R. J., Stevenson, T. J., Xing, L., Newcomb, T. M., Nelson, B., Zeng, W., et al. (2014). Congenital lethal motor neuron disease with a novel defect in ribosome biogenesis. Neurology 82, 1322-1330. doi: 10.1212/WNL.0000000000000305

Carvalho, T., Almeida, F., Calapez, A., Lafarga, M., Berciano, M. T., and CarmoFonseca, M. (1999). The spinal muscular atrophy disease gene product, SMN: a link between SnRNP biogenesis and the Cajal (coiled) body. J. Cell Biol. 147, 715-727. doi: 10.1083/jcb.147.4.715

Cech, T. R., and Steitz, J. A. (2014). The noncoding RNA revolution-trashing old rules to forge new ones. Cell 157, 77-94. doi: 10.1016/j.cell.2014.03.008

Chang, H. C., Hung, W. C., Chuang, Y. J., and Jong, Y. J. (2004). Degradation of survival motor neuron (SMN) protein is mediated via the ubiquitin/proteasome pathway. Neurochem. Int. 45, 1107-1112. doi: 10.1016/j.neuint.2004.04.005

Chen, E., Sharma, M. R., Shi, X., Agrawal, R. K., and Joseph, S. (2014). Fragile $\mathrm{X}$ mental retardation protein regulates translation by binding directly to the ribosome. Mol. Cell 54, 407-417. doi: 10.1016/j.molcel.2014.03.023

Chia, R., Chio, A., and Traynor, B. J. (2018). Novel genes associated with amyotrophic lateral sclerosis: diagnostic and clinical implications. Lancet Neurol. 17, 94-102. doi: 10.1016/S1474-4422(17)30401-5

Cioni, J. M., Lin, J. Q., Holtermann, A. V., Koppers, M., Jakobs, M., A., H., et al. (2019). Late endosomes act as mRNA translation platforms and sustain mitochondria in axons. Cell 176, 56-72.e15. doi: 10.1016/j.cell.2018.11.030

Cleveland, D. W., and Rothstein, J. D. (2001). From Charcot to Lou Gehrig: deciphering selective motor neuron death in ALS. Nat. Rev. Neurosci. 2, 806-819. doi: 10.1038/35097565

Colombrita, C., Zennaro, E., Fallini, C., Weber, M., Sommacal, A., Buratti, E., et al. (2009). TDP-43 is recruited to stress granules in conditions of oxidative insult. J. Neurochem. 111, 1051-1061. doi: 10.1111/j.1471-4159.2009.0 6383.x

Comery, T. A., Harris, J. B., Willems, P. J., Oostra, B. A., Irwin, S. A., Weiler, I. J., et al. (1997). Abnormal dendritic spines in fragile X knockout mice: maturation and pruning deficits. Proc. Natl. Acad. Sci. U.S.A. 94, 5401-5404. doi: $10.1073 /$ pnas.94.10.5401

Court, F. A., Hendriks, W. T., Macgillavry, H. D., Alvarez, J., and Van Minnen, J. (2008). Schwann cell to axon transfer of ribosomes: toward a novel understanding of the role of glia in the nervous system. J. Neurosci. 28, 11024-11029. doi: 10.1523/JNEUROSCI.2429-08.2008

Coyne, A. N., Lorenzini, I., Chou, C. C., Torvund, M., Rogers, R. S., Starr, A., et al. (2017). Post-transcriptional inhibition of Hsc70-4/HSPA8 expression leads to synaptic vesicle cycling defects in multiple models of ALS. Cell Rep. 21, 110-125. doi: 10.1016/j.celrep.2017.09.028

Da Cruz, S., and Cleveland, D. W. (2011). Understanding the role of TDP43 and FUS/TLS in ALS and beyond. Curr. Opin. Neurobiol. 21, 904-919. doi: 10.1016/j.conb.2011.05.029

Darnell, J. C., Van Driesche, S. J., Zhang, C., Hung, K. Y., Mele, A., Fraser, C. E., et al. (2011). FMRP stalls ribosomal translocation on mRNAs linked to synaptic function and autism. Cell 146, 247-261. doi: 10.1016/j.cell.201 1.06 .013

Dewey, C. M., Cenik, B., Sephton, C. F., Dries, D. R., Mayer, P. III, Good, S. K., Johnson, B. A., et al. (2011). TDP-43 is directed to stress granules by sorbitol, a novel physiological osmotic and oxidative stressor. Mol. Cell. Biol. 31, 1098-1108. doi: 10.1128/MCB.01279-10
Dombert, B., Sivadasan, R., Simon, C. M., Jablonka, S., and Sendtner, M. (2014). Presynaptic localization of Smn and hnRNP R in axon terminals of embryonic and postnatal mouse motoneurons. PLOS ONE 9:e110846. doi: 10.1371/journal.pone.0110846

Dreyfuss, G., Kim, V. N., and Kataoka, N. (2002). Messenger-RNA-binding proteins and the messages they carry. Nat. Rev. Mol. Cell. Biol. 3, 195-205. doi: $10.1038 / \mathrm{nrm} 760$

Efimova, A. D., Ovchinnikov, R. K., Roman, A. Y., Maltsev, A. V., Grigoriev, V. V., Kovrazhkina, E. A., et al. (2017). [The FUS protein: physiological functions and a role in amyotrophic lateral sclerosis]. Mol. Biol. 51, 387-399. doi: 10.1134/S0026893317020091

Endo, R., Takashima, N., Nekooki-Machida, Y., Komi, Y., Hui, K. K., Takao, M., et al. (2018). TAR DNA-binding protein 43 and disrupted in schizophrenia 1 coaggregation disrupts dendritic local translation and mental function in frontotemporal lobar degeneration. Biol. Psychiatr. 84, 509-521. doi: 10.1016/j.biopsych.2018.03.008

Fallini, C., Donlin-Asp, P. G., Rouanet, J. P., Bassell, G. J., and Rossoll, W. (2016). Deficiency of the survival of motor neuron protein impairs mRNA localization and local translation in the growth cone of motor neurons. J. Neurosci. 36, 3811-3820. doi: 10.1523/JNEUROSCI.2396-15.2016

Fallini, C., Rouanet, J. P., Donlin-Asp, P. G., Guo, P., Zhang, H., Singer, R. H., et al. (2014). Dynamics of survival of motor neuron (SMN) protein interaction with the mRNA-binding protein IMP1 facilitates its trafficking into motor neuron axons. Dev. Neurobiol. 74, 319-332. doi: 10.1002/dneu.22111

Fallini, C., Zhang, H., Su, Y., Silani, V., Singer, R. H., Rossoll, W., et al. (2011). The survival of motor neuron (SMN) protein interacts with the mRNA-binding protein $\mathrm{HuD}$ and regulates localization of poly(A) mRNA in primary motor neuron axons. J. Neurosci. 31, 3914-3925. doi: 10.1523/JNEUROSCI.3631-10.2011

Farley-Barnes, K. I., Ogawa, L. M., and Baserga, S. J. (2019). Ribosomopathies: old concepts, new controversies. Trends Genet. 35, 754-767. doi: 10.1016/j.tig.2019.07.004

Flannery, A. V., Hirst, M. C., Knight, S. J., Ritchie, R. J., and Davies, K. E. (1995). The fragile X syndrome. Biochim. Biophys. Acta 1271, 293-303. doi: 10.1016/0925-4439(95)00046-7

Fratta, P., Mizielinska, S., Nicoll, A. J., Zloh, M., Fisher, E. M., Parkinson, G., et al. (2012). C9orf72 hexanucleotide repeat associated with amyotrophic lateral sclerosis and frontotemporal dementia forms RNA G-quadruplexes. Sci. Rep. 2:1016. doi: $10.1038 /$ srep01016

Freibaum, B. D., Chitta, R. K., High, A. A., and Taylor, J. P. (2010). Global analysis of TDP-43 interacting proteins reveals strong association with RNA splicing and translation machinery. J. Proteome Res. 9, 1104-1120. doi: $10.1021 /$ pr901076y

Gabanella, F., Carissimi, C., Usiello, A., and Pellizzoni, L. (2005). The activity of the spinal muscular atrophy protein is regulated during development and cellular differentiation. Hum. Mol. Genet. 14, 3629-3642. doi: 10.1093/hmg/ddi390

Genuth, N. R., and Barna, M. (2018). The discovery of ribosome heterogeneity and its implications for gene regulation and organismal life. Mol. Cell 71, 364-374. doi: 10.1016/j.molcel.2018.07.018

Gershoni-Emek, N., Altman, T., Ionescu, A., Costa, C. J., Gradus-Pery, T., Willis, D. E., et al. (2018). Localization of RNAi machinery to axonal branch points and growth cones is facilitated by mitochondria and is disrupted in ALS. Front. Mol. Neurosci. 11:311. doi: 10.3389/fnmol.2018.00311

Grimmler, M., Bauer, L., Nousiainen, M., Korner, R., Meister, G., and Fischer, U. (2005). Phosphorylation regulates the activity of the SMN complex during assembly of spliceosomal U snRNPs. EMBO Rep. 6, 70-76. doi: 10.1038/sj.embor.7400301

Groen, E. J., Fumoto, K., Blokhuis, A. M., Engelen-Lee, J., Zhou, Y., Van Den Heuvel, D. M., et al. (2013). ALS-associated mutations in FUS disrupt the axonal distribution and function of SMN. Hum. Mol. Genet. 22, 3690-3704. doi: 10.1093/hmg/ddt222

Hengst, U., Cox, L. J., Macosko, E. Z., and Jaffrey, S. R. (2006). Functional and selective RNA interference in developing axons and growth cones. J. Neurosci. 26, 5727-5732. doi: 10.1523/JNEUROSCI.5229-05.2006

Hua, Y., Sahashi, K., Rigo, F., Hung, G., Horev, G., Bennett, C. F., et al. (2011). Peripheral SMN restoration is essential for long-term rescue of a severe spinal muscular atrophy mouse model. Nature 478, 123-126. doi: $10.1038 /$ nature 10485 
Hua, Y., Vickers, T. A., Okunola, H. L., Bennett, C. F., and Krainer, A. R. (2008). Antisense masking of an hnRNP A1/A2 intronic splicing silencer corrects SMN2 splicing in transgenic mice. Am. J. Hum. Genet. 82, 834-848. doi: 10.1016/j.ajhg.2008.01.014

Huttelmaier, S., Zenklusen, D., Lederer, M., Dictenberg, J., Lorenz, M., Meng, X., et al. (2005). Spatial regulation of beta-actin translation by Src-dependent phosphorylation of ZBP1. Nature 438, 512-515. doi: 10.1038/nature04115

Ifrim, M. F., Williams, K. R., and Bassell, G. J. (2015). Single-molecule imaging of PSD-95 mRNA translation in dendrites and its dysregulation in a mouse model of fragile $\mathrm{X}$ syndrome. J. Neurosci. 35, 7116-7130. doi: 10.1523/JNEUROSCI.2802-14.2015

Ishiguro, A., Kimura, N., Watanabe, Y., Watanabe, S., and Ishihama, A. (2016). TDP-43 binds and transports G-quadruplex-containing mRNAs into neurites for local translation. Genes Cells 21, 466-481. doi: 10.1111/gtc.12352

Jablonka, S., and Sendtner, M. (2017). Developmental regulation of SMN expression: pathophysiological implications and perspectives for therapy development in spinal muscular atrophy. Gene Ther. 24, 506-513. doi: $10.1038 /$ gt.2017.46

Janusz, A., Milek, J., Perycz, M., Pacini, L., Bagni, C., Kaczmarek, L., et al. (2013). The Fragile $\mathrm{X}$ mental retardation protein regulates matrix metalloproteinase 9 mRNA at synapses. J. Neurosci. 33, 18234-18241. doi: 10.1523/JNEUROSCI.2207-13.2013

Jordanova, A., Irobi, J., Thomas, F. P., Van Dijck, P., Meerschaert, K., Dewil, M., et al. (2006). Disrupted function and axonal distribution of mutant tyrosyltRNA synthetase in dominant intermediate Charcot-Marie-Tooth neuropathy. Nat. Genet. 38, 197-202. doi: 10.1038/ng1727

Kamelgarn, M., Chen, J., Kuang, L., Jin, H., Kasarskis, E. J., and Zhu, H. (2018). ALS mutations of FUS suppress protein translation and disrupt the regulation of nonsense-mediated decay. Proc. Natl. Acad. Sci. U.S.A. 115, E11904-E11913. doi: $10.1073 /$ pnas. 1810413115

Kawahara, Y., and Mieda-Sato, A. (2012). TDP-43 promotes microRNA biogenesis as a component of the Drosha and Dicer complexes. Proc. Natl. Acad. Sci. U.S.A. 109, 3347-3352. doi: 10.1073/pnas.1112427109

Kenneson, A., and Warren, S. T. (2001). The female and the fragile X reviewed. Semin. Reprod. Med. 19, 159-165. doi: 10.1055/s-2001-15401

Kiebler, M. A., and Bassell, G. J. (2006). Neuronal RNA granules: movers and makers. Neuron 51, 685-690. doi: 10.1016/j.neuron.2006.08.021

Kim, J. K., Caine, C., Awano, T., Herbst, R., and Monani, U. R. (2017). Motor neuronal repletion of the NMJ organizer, Agrin, modulates the severity of the spinal muscular atrophy disease phenotype in model mice. Hum. Mol. Genet. 26, 2377-2385. doi: 10.1093/hmg/ddx124

Krichevsky, A. M., and Kosik, K. S. (2001). Neuronal RNA granules: a link between RNA localization and stimulation-dependent translation. Neuron 32, 683-696. doi: 10.1016/S0896-6273(01)00508-6

Kye, M. J., Liu, T., Levy, S. F., Xu, N. L., Groves, B. B., Bonneau, R., et al. (2007). Somatodendritic microRNAs identified by laser capture and multiplex RT-PCR. RNA 13, 1224-1234. doi: 10.1261/rna.480407

Kye, M. J., Niederst, E. D., Wertz, M. H., Goncalves Ido, C., Akten, B., Dover, K. Z., et al. (2014). SMN regulates axonal local translation via miR183/mTOR pathway. Hum. Mol. Genet. 23, 6318-6331. doi: 10.1093/hmg/ ddu350

Lee, E. B., Lee, V. M., and Trojanowski, J. Q. (2011). Gains or losses: molecular mechanisms of TDP43-mediated neurodegeneration. Nat. Rev. Neurosci. 13, 38-50. doi: 10.1038/nrn3121

Ling, S. C., Albuquerque, C. P., Han, J. S., Lagier-Tourenne, C., Tokunaga, S., Zhou, H., et al. (2010). ALS-associated mutations in TDP-43 increase its stability and promote TDP-43 complexes with FUS/TLS. Proc. Natl. Acad. Sci. U.S.A. 107, 13318-13323. doi: 10.1073/pnas.1008227107

Liu, Q., and Dreyfuss, G. (1996). A novel nuclear structure containing the survival of motor neurons protein. EMBO J. 15, 3555-3565. doi: 10.1002/j.1460-2075.1996.tb00725.x

Lopez-Erauskin, J., Tadokoro, T., Baughn, M. W., Myers, B., McalonisDownes, M., Chillon-Marinas, C., et al. (2018). ALS/FTD-linked mutation in FUS suppresses intra-axonal protein synthesis and drives disease without nuclear loss-of-function of FUS. Neuron 100, 816-830.e817. doi: 10.1016/j.neuron.2018.09.044

Lorson, C. L., Hahnen, E., Androphy, E. J., and Wirth, B. (1999). A single nucleotide in the SMN gene regulates splicing and is responsible for spinal muscular atrophy. Proc. Natl. Acad. Sci. U.S.A. 96, 6307-6311. doi: $10.1073 /$ pnas.96.11.6307

Lorson, C. L., Strasswimmer, J., Yao, J. M., Baleja, J. D., Hahnen, E., Wirth, B., et al. (1998). SMN oligomerization defect correlates with spinal muscular atrophy severity. Nat. Genet. 19, 63-66. doi: 10.1038/ng0598-63

Lugli, G., Larson, J., Martone, M. E., Jones, Y., and Smalheiser, N. R. (2005). Dicer and $\mathrm{eIF} 2 \mathrm{c}$ are enriched at postsynaptic densities in adult mouse brain and are modified by neuronal activity in a calpain-dependent manner. J. Neurochem. 94, 896-905. doi: 10.1111/j.1471-4159.2005.03224.x

Maddirevula, S., Alsaif, H. S., Ibrahim, N., and Alkuraya, F. S. (2019). A de novo mutation in FMR1 in a patient with intellectual disability. Eur. J. Med. Genet. doi: 10.1016/j.ejmg.2019.103763. [Epub ahead of print].

Matsumoto, M., Setou, M., and Inokuchi, K. (2007). Transcriptome analysis reveals the population of dendritic RNAs and their redistribution by neural activity. Neurosci. Res. 57, 411-423. doi: 10.1016/j.neures.2006.11.015

Maurin, T., Lebrigand, K., Castagnola, S., Paquet, A., Jarjat, M., Popa, A., et al. (2018). HITS-CLIP in various brain areas reveals new targets and new modalities of RNA binding by fragile $\mathrm{X}$ mental retardation protein. Nucleic Acids Res. 46, 6344-6355. doi: 10.1093/nar/gky267

May, S., Hornburg, D., Schludi, M. H., Arzberger, T., Rentzsch, K., Schwenk, B. M., et al. (2014). C9orf72 FTLD/ALS-associated Gly-Ala dipeptide repeat proteins cause neuronal toxicity and Unc119 sequestration. Acta Neuropathol. 128, 485-503. doi: 10.1007/s00401-014-1329-4

Mcdonald, K. K., Aulas, A., Destroismaisons, L., Pickles, S., Beleac, E., Camu, W., et al. (2011). TAR DNA-binding protein 43 (TDP-43) regulates stress granule dynamics via differential regulation of G3BP and TIA-1. Hum. Mol. Genet. 20, 1400-1410. doi: 10.1093/hmg/ddr021

Mendell, J. R., Al-Zaidy, S., Shell, R., Arnold, W. D., Rodino-Klapac, L. R., Prior, T. W., et al. (2017). Single-dose gene-replacement therapy for spinal muscular atrophy. N. Engl. J. Med. 377, 1713-1722. doi: 10.1056/NEJMoa1706198

Monani, U. R., Sendtner, M., Coovert, D. D., Parsons, D. W., Andreassi, C., Le, T. T., et al. (2000). The human centromeric survival motor neuron gene (SMN2) rescues embryonic lethality in $\mathrm{Smn}(-/-)$ mice and results in a mouse with spinal muscular atrophy. Hum. Mol. Genet. 9, 333-339. doi: 10.1093/hmg/9.3.333

Mourelatos, Z., Abel, L., Yong, J., Kataoka, N., and Dreyfuss, G. (2001). SMN interacts with a novel family of hnRNP and spliceosomal proteins. EMBO J. 20, 5443-5452. doi: 10.1093/emboj/20.19.5443

Mourelatos, Z., Dostie, J., Paushkin, S., Sharma, A., Charroux, B., Abel, L., et al. (2002). miRNPs: a novel class of ribonucleoproteins containing numerous microRNAs. Genes Dev. 16, 720-728. doi: 10.1101/gad.974702

Muddashetty, R. S., Nalavadi, V. C., Gross, C., Yao, X., Xing, L., Laur, O., et al. (2011). Reversible inhibition of PSD-95 mRNA translation by miR125a, FMRP phosphorylation, and mGluR signaling. Mol. Cell 42, 673-688. doi: 10.1016/j.molcel.2011.05.006

Muller, K., Schnatz, A., Schillner, M., Woertge, S., Muller, C., Von Graevenitz, I., et al. (2018). A predominantly glial origin of axonal ribosomes after nerve injury. Glia 66, 1591-1610. doi: 10.1002/glia.23327

Nguyen, H. P., Van Broeckhoven C., and van der Zee, J. (2018). ALS genes in the genomic era and their implications for FTD. Trends in Genet. 34, 404-423. doi: 10.1016/j.tig.2018.03.001

Nussbacher, J. K., Tabet, R., Yeo, G. W., and Lagier-Tourenne, C. (2019). Disruption of RNA metabolism in neurological diseases and emerging therapeutic interventions. Neuron 102, 294-320. doi: 10.1016/j.neuron.2019.03.014

Otter, S., Grimmler, M., Neuenkirchen, N., Chari, A., Sickmann, A., and Fischer, U. (2007). A comprehensive interaction map of the human survival of motor neuron (SMN) complex. J. Biol. Chem. 282, 5825-5833. doi: 10.1074/jbc.M608528200

Ottesen, E. W., Singh, N. N., Luo, D., and Singh, R. N. (2018). High-affinity RNA targets of the Survival Motor Neuron protein reveal diverse preferences for sequence and structural motifs. Nucleic Acids Res. 46, 10983-11001. doi: 10.1093/nar/gky770

Pelletier, J., and Sonenberg, N. (2019). The organizing principles of eukaryotic ribosome recruitment. Annu. Rev. Biochem. 88, 307-335. doi: 10.1146/annurev-biochem-013118-111042

Pesiridis, G. S., Lee, V. M., and Trojanowski, J. Q. (2009). Mutations in TDP-43 link glycine-rich domain functions to amyotrophic lateral sclerosis. Hum. Mol. Genet. 18, R156-162. doi: 10.1093/hmg/ddp303 
Pinkstaff, J. K., Chappell, S. A., Mauro, V. P., Edelman, G. M., and Krushel, L. A. (2001). Internal initiation of translation of five dendritically localized neuronal mRNAs. Proc. Natl. Acad. Sci. U.S.A. 98, 2770-2775. doi: 10.1073/pnas.051623398

Polymenidou, M., Lagier-Tourenne, C., Hutt, K. R., Huelga, S. C., Moran, J., Liang, T. Y., et al. (2011). Long pre-mRNA depletion and RNA missplicing contribute to neuronal vulnerability from loss of TDP-43. Nat. Neurosci. 14, 459-468. doi: 10.1038/nn.2779

Poulopoulos, A., Murphy, A. J., Ozkan, A., Davis, P., Hatch, J., Kirchner, R., et al. (2019). Subcellular transcriptomes and proteomes of developing axon projections in the cerebral cortex. Nature 565, 356-360. doi: 10.1038/s41586-018-0847-y

Rangaraju, V., Lauterbach, M., and Schuman, E. M. (2019). Spatially stable mitochondrial compartments fuel local translation during plasticity. Cell 176, 73-84.e15. doi: 10.1016/j.cell.2018.12.013

Renton, A. E., Chio, A., and Traynor, B. J. (2014). State of play in amyotrophic lateral sclerosis genetics. Nat. Neurosci. 17, 17-23. doi: 10.1038/nn.3584

Renton, A. E., Majounie, E., Waite, A., Simon-Sanchez, J., Rollinson, S., Gibbs, J. R., et al. (2011). A hexanucleotide repeat expansion in C9ORF72 is the cause of chromosome 9p21-linked ALS-FTD. Neuron 72, 257-268. doi: 10.1016/j.neuron.2011.09.010

Renvoise, B., Querol, G., Verrier, E. R., Burlet, P., and Lefebvre, S. (2012). A role for protein phosphatase PPlgamma in SMN complex formation and subnuclear localization to Cajal bodies. J. Cell. Sci. 125, 2862-2874. doi: 10.1242/jcs.096255

Rihan, K., Antoine, E., Maurin, T., Bardoni, B., Bordonne, R., Soret, J., et al. (2017). A new cis-acting motif is required for the axonal SMN-dependent Anxa2 mRNA localization. RNA 23, 899-909. doi: 10.1261/rna.056788.116

Rosen, D. R., Siddique, T., Patterson, D., Figlewicz, D. A., Sapp, P., Hentati, A., et al. (1993). Mutations in $\mathrm{Cu} / \mathrm{Zn}$ superoxide dismutase gene are associated with familial amyotrophic lateral sclerosis. Nature 362, 59-62. doi: 10.1038/362059a0

Rossi, S., Serrano, A., Gerbino, V., Giorgi, A., Di Francesco, L., Nencini, M., et al. (2015). Nuclear accumulation of mRNAs underlies G4C2-repeat-induced translational repression in a cellular model of C9orf72 ALS. J. Cell. Sci. 128, 1787-1799. doi: 10.1242/jcs. 165332

Scarnati, M. S., Kataria, R., Biswas, M., and Paradiso, K. G. (2018). Active presynaptic ribosomes in the mammalian brain, and altered transmitter release after protein synthesis inhibition. Elife 7:e36697. doi: 10.7554/eLife. 36697.028

Schaeffer, C., Bardoni, B., Mandel, J. L., Ehresmann, B., Ehresmann, C., and Moine, H. (2001). The fragile $\mathrm{X}$ mental retardation protein binds specifically to its mRNA via a purine quartet motif. EMBO J. 20, 4803-4813. doi: $10.1093 / \mathrm{emboj} / 20.17 .4803$

Schoen, M., Reichel, J. M., Demestre, M., Putz, S., Deshpande, D., Proepper, C., et al. (2015). Super-resolution microscopy reveals presynaptic localization of the ALS/FTD related protein FUS in hippocampal neurons. Front. Cell. Neurosci. 9:496. doi: 10.3389/fncel.2015.00496

Schrank, B., Gotz, R., Gunnersen, J. M., Ure, J. M., Toyka, K. V., Smith, A. G., et al. (1997). Inactivation of the survival motor neuron gene, a candidate gene for human spinal muscular atrophy, leads to massive cell death in early mouse embryos. Proc. Natl. Acad. Sci. U.S.A. 94, 9920-9925. doi: 10.1073/pnas.94.18.9920

Seelaar, H., Schelhaas, H. J., Azmani, A., Kusters, B., Rosso, S., Majoor-Krakauer, D., et al. (2007). TDP-43 pathology in familial frontotemporal dementia and motor neuron disease without Progranulin mutations. Brain 130, 1375-1385. doi: 10.1093/brain/awm024

Sephton, C. F., Cenik, C., Kucukural, A., Dammer, E. B., Cenik, B., Han, Y., et al. (2011). Identification of neuronal RNA targets of TDP-43containing ribonucleoprotein complexes. J. Biol. Chem. 286, 1204-1215. doi: 10.1074/jbc.M110.190884

Setola, V., Terao, M., Locatelli, D., Bassanini, S., Garattini, E., and Battaglia, G. (2007). Axonal-SMN (a-SMN), a protein isoform of the survival motor neuron gene, is specifically involved in axonogenesis. Proc. Natl. Acad. Sci. U.S.A. 104, 1959-1964. doi: 10.1073/pnas.0610660104

Shukla, S., and Parker, R. (2016). Hypo- and hyper-assembly diseases of RNA-protein complexes. Trends Mol. Med. 22, 615-628. doi: 10.1016/j.molmed.2016.05.005
Simsek, D., Tiu, G. C., Flynn, R. A., Byeon, G. W., Leppek, K., Xu, A. F., et al. (2017). The mammalian ribo-interactome reveals ribosome functional diversity and heterogeneity. Cell 169, 1051-1065.e1018. doi: 10.1016/j.cell.2017.05.022

Sitzmann, A. F., Hagelstrom, R. T., Tassone, F., Hagerman, R. J., and Butler, M. G. (2018). Rare FMR1 gene mutations causing fragile $\mathrm{X}$ syndrome: a review. Am. J. Med. Genet. A 176, 11-18. doi: 10.1002/ajmg.a.38504

So, E., Mitchell, J. C., Memmi, C., Chennell, G., Vizcay-Barrena, G., Allison, L., et al. (2018). Mitochondrial abnormalities and disruption of the neuromuscular junction precede the clinical phenotype and motor neuron loss in hFUSWT transgenic mice. Hum. Mol. Genet. 27, 463-474. doi: 10.1093/hmg/ddx415

Spaulding, E. L., and Burgess, R. W. (2017). Accumulating evidence for axonal translation in neuronal homeostasis. Front. Neurosci. 11:312. doi: 10.3389/fnins.2017.00312

Sreedharan, J., Blair, I. P., Tripathi, V. B., Hu, X., Vance, C., Rogelj, B., et al. (2008). TDP-43 mutations in familial and sporadic amyotrophic lateral sclerosis. Science 319, 1668-1672. doi: 10.1126/science.1154584

Swinnen, B., and Robberecht, W. (2014). The phenotypic variability of amyotrophic lateral sclerosis. Nat. Rev. Neurol. 10, 661-670. doi: 10.1038/nrneurol.2014.184

Tadesse, H., Deschenes-Furry, J., Boisvenue, S., and Cote, J. (2008). KH-type splicing regulatory protein interacts with survival motor neuron protein and is misregulated in spinal muscular atrophy. Hum. Mol. Genet. 17, 506-524. doi: 10.1093/hmg/ddm327

Terenzio, M., Koley, S., Samra, N., Rishal, I., Zhao, Q., Sahoo, P. K., et al. (2018). Locally translated mTOR controls axonal local translation in nerve injury. Science 359, 1416-1421. doi: 10.1126/science.aan1053

Tiedge, H., and Brosius, J. (1996). Translational machinery in dendrites of hippocampal neurons in culture. J. Neurosci. 16, 7171-7181. doi: 10.1523/JNEUROSCI.16-22-07171.1996

Todd, A. G., Morse, R., Shaw, D. J., Stebbings, H., and Young, P. J. (2010). Analysis of SMN-neurite granules: Core Cajal body components are absent from SMN-cytoplasmic complexes. Biochem. Biophys. Res. Commun. 397 479-485. doi: 10.1016/j.bbrc.2010.05.139

Tollervey, J. R., Curk, T., Rogelj, B., Briese, M., Cereda, M., Kayikci, M., et al. (2011). Characterizing the RNA targets and position-dependent splicing regulation by TDP-43. Nat. Neurosci. 14, 452-458. doi: 10.1038/nn.2778

Tsang, B., Arsenault, J., Vernon, R. M., Lin, H., Sonenberg, N., Wang, L. Y., et al. (2019). Phosphoregulated FMRP phase separation models activity-dependent translation through bidirectional control of mRNA granule formation. Proc. Natl. Acad. Sci. U.S.A. 116, 4218-4227. doi: 10.1073/pnas.1814385116

Vance, C., Rogelj, B., Hortobagyi, T., De Vos, K. J., Nishimura, A. L., Sreedharan, J., et al. (2009). Mutations in FUS, an RNA processing protein, cause familial amyotrophic lateral sclerosis type 6. Science 323, 1208-1211. doi: $10.1126 /$ science. 1165942

Veo, B. L., and Krushel, L. A. (2009). Translation initiation of the human tau mRNA through an internal ribosomal entry site. J. Alzheimers Dis. 16, 271-275. doi: 10.3233/JAD-2009-0978

Verkerk, A. J., Pieretti, M., Sutcliffe, J. S., Fu, Y. H., Kuhl, D. P., Pizzuti, A., et al. (1991). Identification of a gene (FMR-1) containing a CGG repeat coincident with a breakpoint cluster region exhibiting length variation in fragile X syndrome. Cell 65, 905-914. doi: 10.1016/0092-8674(91)90397-H

Wan, L., Ottinger, E., Cho, S., and Dreyfuss, G. (2008). Inactivation of the SMN complex by oxidative stress. Mol. Cell 31, 244-254. doi: 10.1016/j.molcel.2008.06.004

Wang, B., Pan, L., Wei, M., Wang, Q., Liu, W. W., Wang, N., et al. (2015). FMRP-mediated axonal delivery of miR-181d regulates axon elongation by locally targeting Map1b and Calm1. Cell Rep. 13, 2794-2807. doi: 10.1016/j.celrep.2015.11.057

Weiler, I. J., and Greenough, W. T. (1999). Synaptic synthesis of the Fragile $\mathrm{X}$ protein: possible involvement in synapse maturation and elimination. Am. J. Med. Genet. 83, 248-252. doi: 10.1002/(SICI)1096-8628(19990402)83:4<248::AID-AJMG3 > 3.0.CO;2-1

Winton, M. J., Igaz, L. M., Wong, M. M., Kwong, L. K., Trojanowski, J. Q., and Lee, V. M. (2008). Disturbance of nuclear and cytoplasmic TAR DNA-binding protein (TDP-43) induces disease-like redistribution, sequestration, and aggregate formation. J. Biol. Chem. 283, 13302-13309. doi: 10.1074/jbc.M800342200 
Zalfa, F., Eleuteri, B., Dickson, K. S., Mercaldo, V., De Rubeis, S., Di Penta, A., et al. (2007). A new function for the fragile $\mathrm{X}$ mental retardation protein in regulation of PSD-95 mRNA stability. Nat. Neurosci. 10, 578-587. doi: 10.1038/n n1893

Zalfa, F., Giorgi, M., Primerano, B., Moro, A., Di Penta, A., Reis, S., et al. (2003). The fragile X syndrome protein FMRP associates with BC1 RNA and regulates the translation of specific mRNAs at synapses. Cell 112, 317-327. doi: 10.1016/S0092-8674(03)00079-5

Zhang, H. L., Pan, F., Hong, D., Shenoy, S. M., Singer, R. H., and Bassell, G. J. (2003). Active transport of the survival motor neuron protein and the role of exon-7 in cytoplasmic localization. J. Neurosci. 23, 6627-6637. doi: 10.1523/JNEUROSCI.23-16-06627.2003

Zhang, M., Ergin, V., Lin, L., Stork, C., Chen, L., and Zheng, S. (2019). Axonogenesis is coordinated by neuron-specific alternative splicing programming and splicing regulator PTBP2. Neuron 101, 690-706.e610. doi: 10.1016/j.neuron.2019.01.022

Zhang, Y. J., Xu, Y. F., Cook, C., Gendron, T. F., Roettges, P., Link, C. D., et al. (2009). Aberrant cleavage of TDP-43 enhances aggregation and cellular toxicity. Proc. Natl. Acad. Sci. U.S.A. 106, 7607-7612. doi: 10.1073/pnas.09006 88106
Zhang, Z., Pinto, A. M., Wan, L., Wang, W., Berg, M. G., Oliva, I., et al. (2013). Dysregulation of synaptogenesis genes antecedes motor neuron pathology in spinal muscular atrophy. Proc. Natl. Acad. Sci. U.S.A. 110, 19348-19353. doi: 10.1073/pnas.1319280110

Zu, T., Liu, Y., Banez-Coronel, M., Reid, T., Pletnikova, O., Lewis, J., et al. (2013). RAN proteins and RNA foci from antisense transcripts in C9ORF72 ALS and frontotemporal dementia. Proc. Natl. Acad. Sci. U.S.A. 110, E4968-4977. doi: 10.1073/pnas.13154 38110

Conflict of Interest: The authors declare that the research was conducted in the absence of any commercial or financial relationships that could be construed as a potential conflict of interest.

Copyright (c) 2020 Thelen and Kye. This is an open-access article distributed under the terms of the Creative Commons Attribution License (CC BY). The use, distribution or reproduction in other forums is permitted, provided the original author(s) and the copyright owner(s) are credited and that the original publication in this journal is cited, in accordance with accepted academic practice. No use, distribution or reproduction is permitted which does not comply with these terms. 